\title{
The Farm Debt Crisis of the 1980s: A Review Essay
}

\author{
Gilbert C. Fite
}

The Farm Debt Crisis of the 1980 s, by Neil E. Harl. Henry A. Wallace Series on Agricultural History and Rural Studies. Ames: Iowa State University Press, 1990. xv, 305 pp. Illustrations, tables, notes, index. $\$ 24.95$ cloth.

The Fall of the Farm Credit Empire, by Ben Sunbury. Ames: Iowa State University Press, 1990. xvi, 264 pp. Illustrations, notes, index. $\$ 27.95$ cloth.

Farming Is in Our Blood: Farm Families in Economic Crisis, by Paul C. Rosenblatt. Ames: Iowa State University Press, 1990. ix, 187 pp. Appendix; notes, index. $\$ 22.95$ cloth.

THE THREE BOOKS under review deal with aspects of the economic problems faced by farm borrowers and their lenders in the 1980s. That was one of those times, common in the twentieth century, when farmers suffered a bust after an inflationary boom. Agriculture experienced several economic ups and downs after World War I, but one of the most devastating periods for many farmers was in the mid-1980s.

As a result of world-wide demand, the prices of American farm commodities began rising sharply in late 1972 and continued unusually high for the next four years. Wheat that had averaged $\$ 1.76$ per bushel in 1972 brought $\$ 3.95$ in 1973 . Corn sold for an average price of $\$ 2.55$ in 1973 and $\$ 3.02$ in 1974, compared to only a little over $\$ 1$ per bushel in the early 1970 s. Such good prices made farmers ecstatic. It seemed as though the earlier surpluses that had so depressed farm commodity

THE ANNALS OF IOWA 51 (Winter 1992). (CThe State Historical Society of Iowa, 1992. 
prices were gone forever. Indeed, government officials, farm papers, and other voices of agriculture indicated either explicitly or implicitly that a new day had dawned for American farmers. Secretary of Agriculture Earl Butz urged farmers to plant from fencerow to fencerow to meet the growing foreign and domestic needs. That seemed like a good idea during the middle 1970 s as prices continued strong.

Many farmers bought more land at high prices, purchased large and expensive machinery to take care of larger acreages, and spent more on their living standards. They had no difficulty obtaining credit from local banks and the Farm Credit System. The Federal Land Banks and Production Credit Associations and the Farmers Home Administration were all ready to extend loans.

Land prices rose rapidly under the influence of strong commodity prices and competition among farmers to buy additional acreage. As farmers' land increased in value, they had more security for additional credit. With easily available credit, and believing that land values would continue to climb, many farmers in the Midwest paid two, three, even four thousand dollars per acre for farmland. Interest rates were high, often as much as 12 or 15 percent. So long as commodity prices remained high and land values advanced-that is, as long as inflationary conditions prevailed-most of the borrowers could meet their debt payments. But if commodity prices dropped and land prices fell substantially, both borrowers and lenders would be in serious financial trouble. That is what occurred in the early 1980s at a time when total farm debt reached about $\$ 200$ billion. By the mid-1980s many farmers owed more than they were worth and went broke. Some banks with large portfolios of farm loans were forced to close their doors. This is the background against which all three of the books under review are set.

NEIL E. HARL'S The Farm Debt Crisis of the 1980s is mostly a personal account of Harl's efforts to alert the country to the approaching farm credit disaster, and his work in trying to solve that vexing problem. Harl, a leading farm economist and agricultural tax expert at Iowa State University, was among the first to warn that a crisis was in the making, both for farmers and 
their lenders. He provides an excellent inside view of how the farm debt crisis unfolded in 1984 and 1985, and of the measures designed to alleviate the crisis.

In the first two chapters, Harl explains how the crisis came about. He is especially critical of the government's encouragement of inflation in the 1960s and 1970s, and of the Federal Reserve Board's abrupt decision in 1979 to reduce inflation, tighten credit, and raise real interest rates. Furthermore, he explains that a stronger dollar weakened export demand, and farm commodity and land prices dropped sharply; between 1981 and 1986 the value of Iowa farmland declined an average of $\$ 1,360$ per acre. These conditions reduced the value of farm assets and lowered farm income to the point where many farmers did not have enough income to pay their debts. Even some of the most efficient farmers failed, according to Harl.

By early 1984 Harl had concluded that the farm debt problem was so serious that some remedial action should be taken before the crisis became even worse. He discussed the matter in academic seminars, talked to the press, visited with bankers, and appeared before congressional committees. He argued that farm debt would have to be restructured, and proposed writing down some of the principal, extending the time for payment, and having the federal government guarantee part of the loan.

Although the farm credit problem seemed headed toward disaster in 1984, the Farm Credit System and officials in the United States Department of Agriculture were slow to admit that a real crisis existed. Harl relates numerous interesting meetings with Farm Credit officials as he tried to point out the need for action to save both borrowers and lenders. But until 1985, despite huge losses, the Farm Credit System indicated that it could work out the problem without federal help. By 1985, however, Harl's views prevailed. The federal government moved toward what became a kind of bailout for the Farm Credit System. Harl discusses briefly the amendments to the Farm Credit Act passed in 1985, 1986, and 1987. He also tells about state efforts to help out, including moratoria against foreclosures. Finally, he lists twelve lessons that should be learned from the farm credit crisis.

The Farm Debt Crisis provides a good overall view of the farm debt problem in the 1980s, and shows the successes and 
failures of an academic from a major land grant university who recognized the problems early and who tried to find practical answers. The book is rather hard reading. It contains many long quotations, has some duplication, and would be improved with some reorganization. Yet it is basic to understanding the farm crisis.

BEN SUNBURY'S The Fall of the Farm Credit Empire also deals with the agricultural credit crisis of the 1980s. Like Harl, Sunbury writes from personal observation and experience. He served as an assistant to three governors of the Farm Credit Administration, the supervisory agency of the Farm Credit System. After providing some background on the system, which originated in 1916, Sunbury concentrates on the years 1985 to 1987, when the system was in greatest danger.

Lending agencies that made up the Farm Credit System, such as the Federal Land Banks and the Production Credit Associations, had outstanding loans of some $\$ 82$ billion by 1983. As both Sunbury and Harl point out, so long as farm prices remained strong and land prices advanced, this huge debt was manageable. But lower commodity prices and dropping land values placed the system in jeopardy. By 1985 and 1986 the Farm Credit System was hemorrhaging from bad loans. During those two years, the system lost about $\$ 5$ billion and had billions more in what bankers call nonperforming loans.

Writing from his inside perspective, Sunbury traces events as they developed from 1985 to 1987 . He agrees with Harl that system officials were slow to realize the seriousness of the problem. Sunbury shows how system spokesmen resisted the idea of federal aid, or some kind of bailout, until it became clear that the Farm Credit System could not endure without government assistance. He discusses the laws of 1985, 1986, and 1987, which were designed to restructure and provide additional capital for the system. The Farm Credit System emerged from this period with less independence and more effective federal supervision.

Sunbury also writes about personalities and politics within the system. He ascribes part of the system's difficulties to poor leadership, especially in the Farm Credit Administration. He 
shows how bureaucracy developed within the system and how efforts were made to protect jobs at the expense of efficiency. But he concludes that, despite its problems in the 1980s, the cooperative Farm Credit System will continue and in all likelihood meet the challenges ahead.

The Harl and Sunbury books complement one another admirably. They cover much of the same ground, but emphasize different aspects of the farm credit crisis. Both authors agree that the main sources of farm credit difficulties in the 1980s were excessive debt, high interest rates, and low farm commodity prices.

PAUL C. ROSENBLATT'S Farming Is in Our Blood: Farm Families in Economic Crisis is an entirely different sort of book. Rosenblatt concentrates on the human stresses and strains experienced by farm families during the mid-1980s. It is one thing to write about a credit crisis in general, and about the agencies providing loans, but what about borrowers who became mired in debt and lost their farms? That is Rosenblatt's concern. A University of Minnesota professor in the Department of Family Social Science and Psychology, Rosenblatt arranged to interview twenty-four farm couples in 1986 who were, or had been, struggling with credit problems.

In the interviews farmers attributed much of their credit problem to lenders. They believed that bankers and government lending agencies had encouraged them to borrow more money than was wise or necessary. Although farmers were critical of lenders, they also blamed some of their misfortune on bad family decisions, such as borrowing heavily to set up a son in farming. The interviews also showed that in many cases farmers placed too much faith in their bankers, and displayed a lack of careful study and scrutiny when obtaining loans.

The stress associated with economic difficulties created a heavy strain on some family relationships. Rosenblatt includes an entire chapter, mostly quotations from husbands and wives, on family problems during financial crisis. Loss of the family farm was a major catastrophe. It not only ended a way of life for the family, it meant the loss of a home. Once farmers realized that they were in a financial crunch, they did everything they could to save the farm. They took off-farm employment, cut 
expenses, and did the best they could to protect their assets. But in follow-up interviews in 1987, Rosenblatt found that only fourteen of the twenty-four families were still farming full- or part-time, and only seven of the fourteen appeared to be financially secure. The credit crisis had taken a severe toll.

The Rosenblatt study provides important insights into the human problems and reactions associated with financial stress on the farm. The extensive quotations from those farmers interviewed give readers a feel for conditions that statistics and economic analysis cannot possibly provide. It is clear from this book that farming really is in farmers' blood.

THE THREE VOLUMES under review combine to paint a vivid picture of the debt problems facing farmers in the 1980s. Iowa State University Press is to be congratulated for publishing these studies. Historians, economists, and sociologists will find the books valuable, but they should also be read by farmers. Farmers could learn a great deal about how to guard against disasters associated with future boom and bust periods, which, according to Harl, will surely be repeated in the future. People may not learn much from history, but they could! 
Copyright of Annals of Iowa is the property of State of Iowa, by \& through the State Historical Society of Iowa and its content may not be copied or emailed to multiple sites or posted to a listserv without the copyright holder's express written permission. However, users may print, download, or email articles for individual use. 